\title{
Aphid Species Colonizing Mugwort (Artemisia vulgaris L.) along the Hungarian Highways
}

\author{
ZS. BASKY \\ Plant Protection Institute, Centre for Agricultural Research, Hungarian Academy of Sciences, \\ Herman Ottó u. 15, H-1022 Budapest, Hungary
}

(Received: 4 April 2016; accepted: 18 April 2016)

\begin{abstract}
Survey of aphids on dicotyledonous herbaceous plants along the Hungarian highways on 33 sampling points revealed the presence of aphid infestation on Artemisia vulgaris L. in 4 locations. Macrosiphoniella artemisiae (Boyer de Fonscolombe, 1841) colonies were present on the youngest parts of the shoots each place. On one of the locations the gall forming Cryptosiphum artemisiae Buckton, 1789 was present. Gall containing shoots of the mugwort were collected to rear aphid nymphs to adult. On these shoots the overlooked Brachycaudus cardui Linnaeus, 1758 individuals developed into apterae. Artemisia absinthium L. was present on one location. This plant accommodated Macrosiphoniella absinthii (Linnaeus, 1758).
\end{abstract}

Keywords: Artemisia vulgaris, gall forming, Cryptosiphum artemisiae.

Mugwort, Artemisia vulgaris L., belongs to family Asteraceae. It is a perennial weed species having ramifying rhizomes. Each ramification develops more or less equally developed erected above-ground stems (Ujvárosi, 1973). The stems are corrugated lengthwise; the colour is generally green or brown at the base and purplish at the upper part. At the end of the growing season ramification occurs and branches develop accommodating flower spikes (Holm et al., 1997). The rhizomes branching at the nodes and reaching depths of 7-18 cm in the soil (Barney and DiTomasso, 2003). Mugwort is native to Europe, it can be found along roadsides, and in waste areas, it cannot stand the soil cultivation of the arable crops (Kazinczi, 2016 pers. comm.). It was introduced to North America (Holm et al., 1997; El-Sahhar et al., 2010) where it became a noxious weed in nursery crops, often occurring along roadsides and is widespread in waste areas (Barney and DiTomasso, 2003). Mugwort is a rhizomatous perennial weed locally reproduced by rhizomes. However, dependent on the specific geographic region, mugwort might reproduce from seeds. Normally propagation in this species mainly occurs via fragments of the shallow rhizomes (Holm et al., 1997).

Survey along the Hungarian motorway system revealed the presence of A. artemisiifolia on 4 locations. On one location a rare gall forming aphid species was found beside the more commonly occurring mugwort feeding aphid species. 


\section{Materials and Methods}

Along the $2655.9 \mathrm{~km}$ long highway network 33 evenly distributed sampling places were marked on reposing places or petrol stations. Aphids were surveyed on host plants from middle of May till the beginning of July in 2011 and 2012. The sampling places are published in Kiss et al. (2013). Aphid colonies were collected with fine camel hair brush and placed into Eppendorf tubes containing 70\% ethanol. Shoots of gall containing plants were collected and transferred into laboratory. Then shoots were placed into water containing Erlenmeyer-flasks and covered by fine mesh organza to keep plants alive until the nymphs developed into apterae. Location, sampling date and host plant name were recorded on the labels placed into the tubes. Apterous individuals were slide mounted using the method of Szalay-Marzsó (1969).

\section{Results and Discussion}

Aphid colonies occurred on 4 locations on A. vulgaris. Macrosiphoniella artemisiae (Boyer de Fonscolombe, 1841) colonised the young shoots of mugwort on the youngest highway section along Budapest (Fig. 1). On sandy soil the artificially established vegetation did not show a vigorous development. Therefore the original flora elements were able to establish successful secondary succession. Mugwort occurred in secondary successions at locations Szilas N 47³4'02" E $19^{\circ} 08^{\prime}$ 57', Kisbag N $47^{\circ} 37^{\prime} 36^{\prime \prime}$ E $19^{\circ}$ 26’36" M0 0 km N 47²7'42" E 18 52'41'. A Nature reserve area was intentionally chosen at Dunakeszi bridge location N 47 $36^{\prime} 11^{\prime \prime}$ E $19^{\circ} 05^{\prime} 48^{\prime \prime}$. At M0 $0 \mathrm{~km}$ red galls occurred on the beginning of June on mugwort plants (Fig. 2). At the time of collection

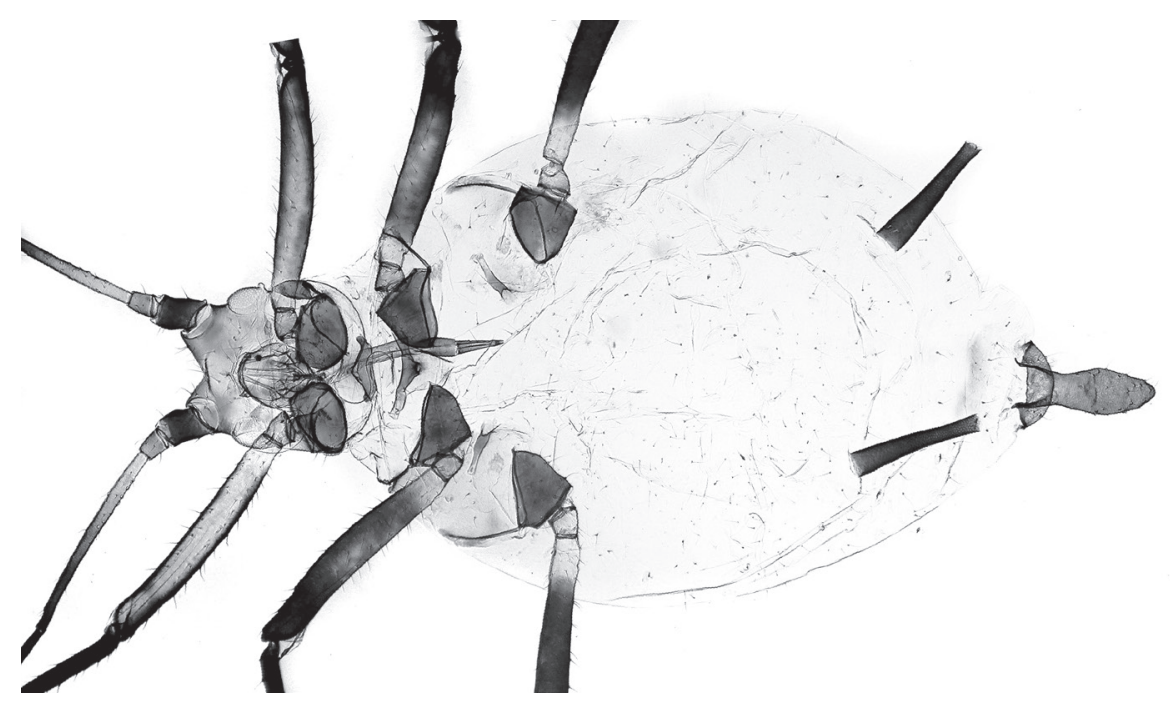

Fig. 1. Uroleucon artemisiae apterous female 


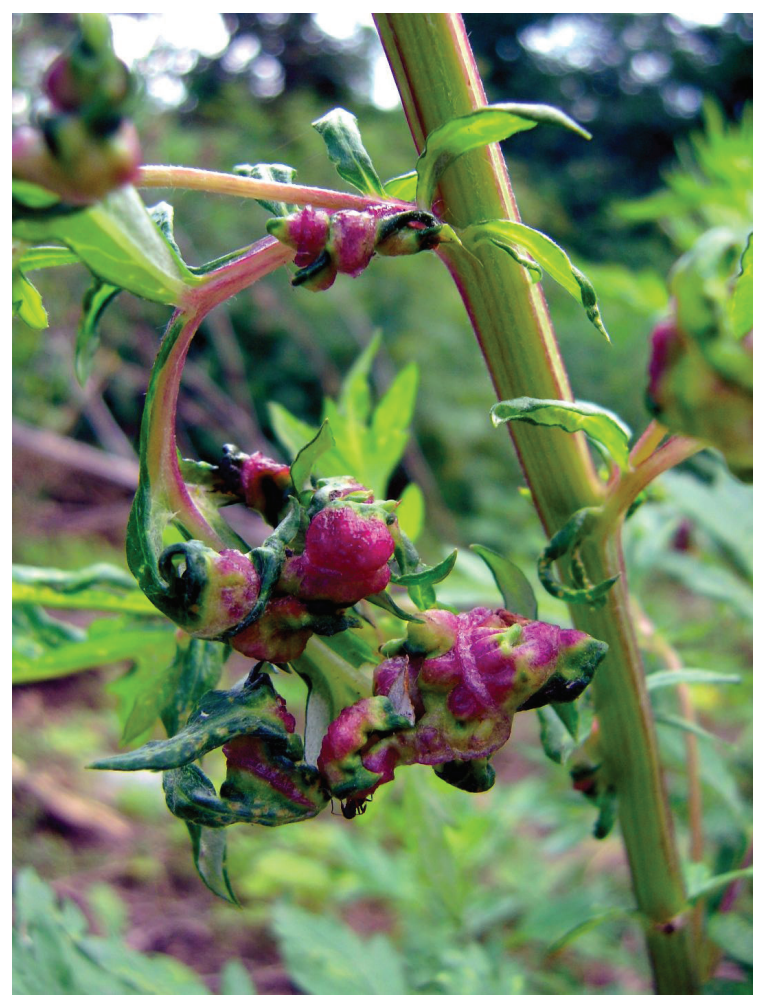

Fig. 2. Galls on the leaves of Artemisia vulgaris caused by Cryptosiphum artemisiae

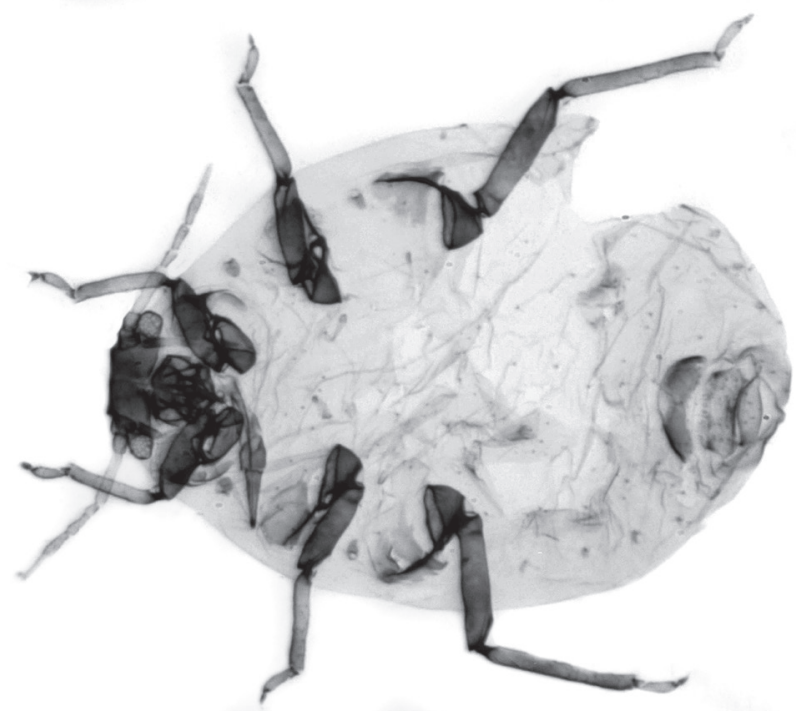

Fig. 3. Cryptosiphum artemisiae apterous female 


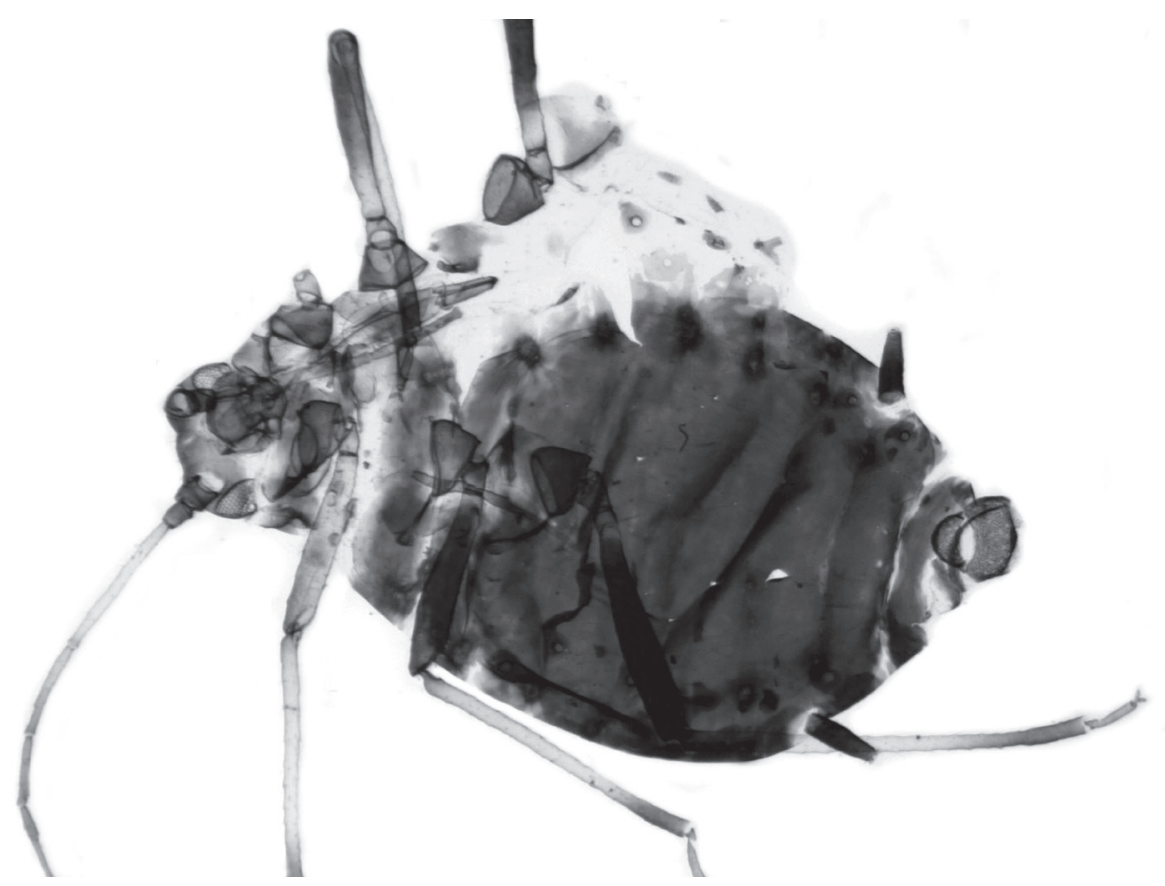

Fig. 4. Brachycaudus cardui apterous female

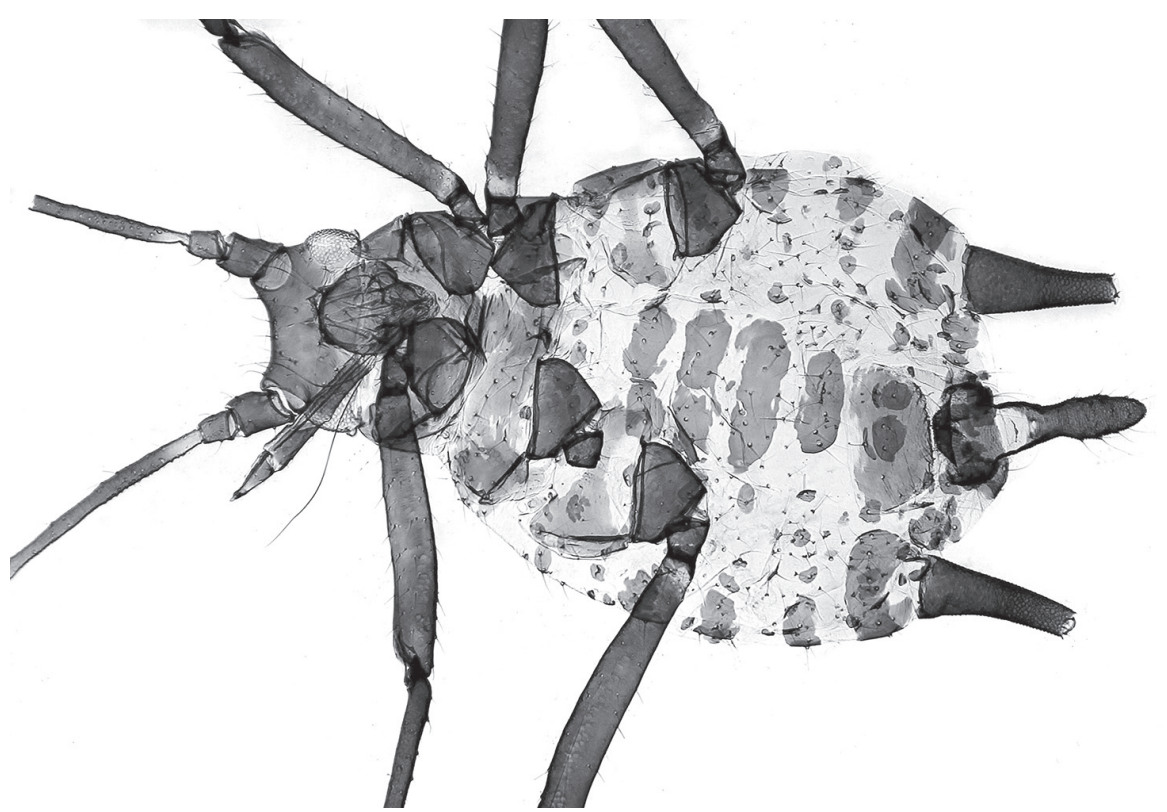

Fig. 5. Macrosiphoniella absinthii apterous female 
yellow nymphs were found in the galls. In the laboratory we kept the shoots alive and 7-12 days later the nymphs developed into apterae.

The gall forming aphid species, Cryptosiphum artemisiae Buckton, 1879 was identified by using the key of Heie (1982). Apterous viviparous females are powdered by greyish wax. Head, antennae, abdominal tergite VIII and cauda have brown pigmentation. Siphunculi hardly visible, pore like. Cauda is short and broadly rounded. Antenna is six segmented, short, $1 / 4$ of the body length. Processus terminalis is $0.3-0.7 \times$ of its base. Body round, almost globular. Cauda is crescent shaped (Fig. 3).

Cryptosiphum artemisiae is widespread in Denmark, Sweden, Norway, Finland, Europe, Asia, India, China, Korea and Japan. It is reported in the checklist of the Hungarian aphid fauna (Ripka, 2008). It is present in Andrásfalvy's collection. He collected alata individuals on 1 June 1968 from Sashegy (Budapest XI district). There is no explanation of the occurrence of different morphs between 1968 and 2012 in the similar season (early summer) in Andrásfalvy and our collection. In our collection there was no any alatiform nymph at all. However, the occurrence of alatae is not coincidence in 1868 . There are 12 alata individuals in the collection of Andrásfalvy and there is no any aptera.

Beside C. artemisiae, two individuals of Brachycaudus cardui developed on the isolated mugwort shoots (Fig. 4). Artemisia absinthii Linnaeus, 1758 was present in one location in Hajdúnánás N 47³4'02" E $19^{\circ} 08^{\prime}$ '57'. This species was colonized by Macrosiphoniella absinthii (Linnaeus, 1758) (Fig. 5). Photos of Macrosiphoniella artemisiae and Macrosiphoniella absinthii were published in Basky (2016).

\section{Acknowledgements}

Special thanks are due to Pál Andrásfalvy for providing his valuable, correctly identified aphid collection for confirming purposes. Andrásfalvy's collection has been catalogued and deposited in ARC HAS Plant Protection Institute. Finally it will be hang over to the Hungarian Natural History Museum.

The author wishes to thank for financial support of OTKA project number 83829. Grateful thanks are due to Dr. Géza Ripka for his valuable advices during manuscript preparation, Ágnes Valiskó Hornyák for mounting the slides and Dr. Éva Szita for the microscopic photography.

\section{Literature}

Barney, J. N. and DiTomasso, A. (2003): The biology of Canadian weeds. 118. Artemisia vulgaris L. Can. J. Plant Sci. 83, 205-215.

Basky, Z. (2016): Aphid species colonizing perennial Asteraceae host species along Hungarian motorways. Acta Phytopathol. et Entomol. Hung. 51, 77-90.

El-Sahhar, K. F., Rania, M. N. and Farag, H. M. (2010): Morphological and anatomical studies of Artemisia vulgaris L. (Asteraceae). I. Morphological characteristics. J. American Science 6, 806-814.

Heie, O. E. (1982): The Aphidoidea (Hemiptera) of Fennoscandinavia and Denmark. III. E. J. Brill/Scandinavian Science Press Ltd., Leiden, Copenhagen, 313 p.

Holm, L., Doll, J., Holm, E., Pancho, J. and Herberger, J. (1997): World Weed: Natural Histories and Distribution. John Wiley and Sons, New York, U.S.A., 1129 p.

Kiss, B., Lengyel, G., Nagy, Z. and Kárpáti, Z. (2013): First record of spotted wing Drosophila [Drosophila suzukii (Matsumura, 1931)] in Hungary. Növényvédelem 49, 97-99. 
Ripka, G. (2008): Checklist of the Aphidoidea and Phylloxeroidea of Hungary (Hemiptera: Sternorrhyncha. Folia Entomol. Hung. 69, 19-157.

Szalay-Marzsó, L. (1969): Levéltetvek a kertészetben. (Aphids in horticulture.) Mezőgazdasági Kiadó, Budapest, $186 \mathrm{p}$.

Ujvárosi, M. (1973): Gyomnövények. (Weeds.) Mezőgazdasági Kiadó, Budapest, 833 p. 